IJLRES - International Journal on Language, Research and Education Studies

ISSN: 2580-6777 (p); 2580-6785 (e)

Vol. 1, No. 2, 2017

Page: 212 - 225

\title{
COMMUNICATION OF ISLAMIC CIVIC ORGANIZATION IN OVERCOMING THE CONFLICT AND IMAGING AT NORTH SUMATERA (ANALYSIS OF MUHAMMADIYAH)
}

\author{
Hasnun Jauhari Ritonga \\ hasnunjritonga@gmail.com \\ Faculty of Da'wah, State Islamic University of North Sumatra, Indonesia \\ Syukur Kholil \\ syukurkholil@uinsu.ac.id \\ School of Post Graduate, State Islamic University of North Sumatra, Indonesia \\ Yusnadi \\ yusnadi@uinsu.ac.id \\ State Islamic University of North Sumatra, Indonesia
}

\begin{abstract}
This study aims to show that organizational communication becomes very important in the life of the organization. The research results show that The nature of coordination is the realization of a cooperation, mutual respect or appreciation of duties and functions and responsibilities due to the principle of the division of tasks, functionalization and consequence of a range or level of control, in which the leader must foster, guide, direct and control various activities in a large and complex organization, where various functions and activities must be performed by various units of work (units) that must be done in an integrated and simultaneous manner. Taking into account the existence of Muhammadiyah North Sumatra as part of a large organization in Indonesia, in principle coordination of tasks running vertically, horizontally, and functionally. Vertical coordination is carried out in order to harmonious and synchronous cooperation harmonization from higher-level institutions to other institutions of lower degree. Horizontal coordination is done in order to harmonious and synchronous cooperation between institutions or equivalent units. While functional coordination is done in order to harmonious harmonious and synchronous cooperation between institutions that have similarities in job functions such as among fellow heads of public relations
\end{abstract}

Key Words; Communication, Islamic Civic Organization, The Conflict and Imaging

\section{INTRODUCTION}

The importance of communication in the organization so far no one can deny it. Even so many studies have concluded that organizational communication is part of the effort to minimize conflicts within the organization, especially as a result of miscommunication. Conducive organizational climate one of them is influenced by the effectiveness of organizational communication. Job satisfaction is also one of them caused by harmonious communication in organiasasi. And so on, various conclusions 
of research that show the importance of organizational communication. In fact, these conclusions appear not just, not contemporary issues, but have been for a long time. To this as R. Wayne Pace \& Don F. Faules puts it: "Traditional literature on this field emphasizes that communication and organizational success are related. Improving organizational communication means improving the organization ". Suhaediman Yuwono even noted at least there are three things that become positive impact if organizational communication is running effectively, those are:

1. The rising of proficiency in the execution of work because the descriptions necessary to carry out the work become available and become clear also the things expected of a responsibility. The effect of work proficiency is also obtained because communication is an input that encourages creative thinking.

2. The rising of encouragement of work (performance) through communication then the curiosity that if not channeled can reduce morale can not be met. With communication can be fulfilled the needs of personnel in carrying out its duties, also can understand why they work and then can be encouraged enthusiasm.

3. Communication is the main tool for personnel to cooperate. Communication helps to unify organizations by allowing personnel to influence and imitate one another. ${ }^{1}$

The importance of organizational communication is of course not only valid internally, but also externally. External communication understood as a form of communication that takes place between the organization and the people outside the organization aims to establish harmonious relationships with communities outside the organization, customers and government. Usually this work is carried out by public relations or public relations division (human / public relation officer) in one organization. ${ }^{2}$ Even the importance of communication is not only in relation to building the organization, but also building the lives of individuals, families, and society in general.

\footnotetext{
Page 4 .

2 Onong Uchjana Effendy (1985). Ilmu Komunikasi: Teori dan Praktek. Bandung: Remaja Rosdakarya. Page 128.
}

1 Suhaediman Yuwono. (1985). Ikhtisar Komunikasi Administrasi. Yogyakarta: Liberty. 


\section{Communication of Islamic Civic Organization in Overcoming the Conflict and Imaging at North Sumatera (analysis of muhammadiyah)}

In relation to the above, Jalaluddin Rakhmat reported that in 1970 in California, a 50-year-old mother escaped from her home after a fight with her 70-year-old husband. He brought his son, 13 year old girl. They came to ask for help to the social welfare officer. But the officer noticed a strange thing to the girl he was carrying. His behavior does not show a normal child. His body was hunched, scrawny, dirty, and sad. All the while he does not stop spitting. None of them spoke. Officer thinks this girl has been molested by her mother. The police were called, and both parents had to deal with the court. On the day of the trial, the girl's father killed herself with a gun. He left the note, "The world will never understand". The investigation later revealed that Genie, as the pseudonym of the girl, went through her childhood in hell that her own father made. Since his father's father tied Genie in a tight seat. All day he can not move his hands and feet. At night he was placed in a kind of iron cage. Often he is starving. But if Genie cries, his father beats him. The father never spoke. The mother is too blind to take care of it. Genielah's older brother is finally trying to feed and drink. Itupun according to his father's command must be done quietly, without making a sound. Genie had never heard a conversation. Her sister and her mother often chatted with a whisper, for fear of her father. When Genie was admitted to the hospital, it was not known whether to speak or understand people's speech. She was silent. His versatility is no different from a one-year-old child. The world may never understand. But the discovery of Genie has invited the curiosity of psychologists, linguists, neurologists, and those who study the development of the human brain. Genie is a rare example of a human child who since childhood has almost no chance to communicate. Genie's discovery drew attention. Genie is not equipped with the skills to express her thoughts in the form of symbols that others understand. ${ }^{3}$

Interesting facts in human life is the communication process run by each individual is a social process. That is, communication is a social process that is an integral part of society. ${ }^{4}$ This indicates that every communication can not be separated from one's relationship with the environment or society. In fact, as the term of organizational communication evolves, there are also various approaches to mapping the relevance of communication within the organization to the various phenomena that

${ }^{3}$ Jalaluddin Rakhmat. (2005) Psikologi Komunikasi (Bandung: Remaja Rosdakarya, 2005), Printed 23, Page 1-2.

${ }^{4}$ Nurudin, (2008). Sistem Komunikasi Indonesia. Jakarta: RajaGrafindo Persada, Page 47. 


\section{Hasnun Jauhari Ritonga}

appear to support or deny its existence within the organization. Communication within the organization must be intensive and there should be no single part or person within the organization feel alienated (alienated) for not getting information from others. Network communication within the organization is very important in order to integrate components or elements that exist within the organization. The developed approach associated with it is called an integrative perspective

An integrative perspective attempts to complement the classical and humane approach by trying to unify the whole view in organizational analysis. Adding technological factors and environmental influences outside the organization as factors that contribute to organizational survival. One model that can be used to describe this approach is system theory. The system theory that originated its birth spearheaded by Scott $(1961)^{5}$ view organization as a relation of various components or elements that are interdependent to each other in order to achieve organizational goals. ${ }^{6}$ The emphasis is that every element in the organization has its own role and is interconnected with each other.

The existence of the organization as a system is also inseparable from other larger systems, so the continuity of the organization is influenced by many things, including technology and other factors contained within the environment of an organization such as political, economic and social environment. Thus, the communication that occurs within the organization when based on an integrative perspective as seen above applies the pattern that varies greatly between one organization with another organization.

Viewed from the side of the establishment of an organization, Muhammadiyah, Nahdlatul Ulama (hereinafter abbreviated as NU only), and Al Jam'iyatul Washliyah (hereinafter abbreviated as Al Washliyah only) are some of the organizations that have implemented internal organizational communication. It is seen from the organizational structure of each institution. In addition it can also be understood from the determination of leadership that has been running periodically according to the rules of their respective organizations. After the formation of organizational structure in each regional board, both Muhammadiyah, NU, and Al Washliyah, usually conduct Working Meeting (Raker) to discuss work program and other things to be

\footnotetext{
${ }^{5}$ Pace \& Faules, Komunikasi Organisasi, Page 63.

${ }^{6}$ Arni Muhammad, (2011). Komunikasi Organisasi. Jakarta: Bumi Aksara. Page 46-47.
} 


\section{Communication of Islamic Civic Organization in Overcoming the Conflict and Imaging at North Sumatera (analysis of muhammadiyah)}

implemented during the stewardship period. This work meeting is usually followed up with meetings in later periods during the stewardship period. In addition to internal meetings, there are also assignments, coordination among administrators, assignment letters or summons, and so on. These are all formal patterns of communication that take place in all three organizations. While informal communication usually exists or arises when there is an issue, both related to the organization and the persons within the organization. Thus, it can be said that internal organizational communication, both in Muhammadiyah, NU, and Al Washliyah, has been running according to the pattern and rules of each organization, although to examine matters related to internal organizational communication should be conducted in more in-depth assessment.

Based on the temporary search, the practice of external organizational communication between Muhammadiyah, NU, and Al Washliyah, is already underway. It's just about the pattern, shape, role, or model of external organizational communication is done to be studied in more depth. In addition, essentially every organization born of society is inseparable from its responsibility to society as well. Therefore, when an organization's external organization communications are going well it will benefit the organization itself. The organization will be favored by the community and supported its presence in the midst of Muslims. To conclude that internal and external organizational communication in and between the three institutions to be researched, it is necessary to in-depth study through research. Based on these needs which are all related to the two forms of organizational communication (internal and external), this research becomes important. On the other hand, to understand the external communications made between the Muhammadiyah, NU, and Al Washliyah organizations can be examined on the basis of the birthright of each.

\section{LITERATURE REVIEW}

According to R. Wayne Pace \& Don F. Faules to understand the meaning of organizational communication can be seen from two kinds of definitions, namely the functional and interpretative definitions. ${ }^{7}$ Functionally organizational communication is defined as a show and interpretation of messages between communications units

\footnotetext{
7 Pace \& Faules, Komunikasi Organisasi, Page 31-33.
} 
that are part of a particular organization. In this case the existing communication units within the organization always show hierarchical relationships between one another and function in an environment. ${ }^{8}$ Here what happens is the performances and interpretation of messages among fellow members of the organization that can happen anytime. The communication takes place simultaneously in relation to each other in the framework of interactions that occur within the organization. It is also referred to as an organizational communication system. ${ }^{9}$

The above definition basically tends to emphasize communication as the handling of an "in" or "for" message-depending exchange of messages indicating organizational boundaries, which ultimately shows the structure as an information network within an organization. Thus, the communication that occurs clearly has been arranged and runs along with the boundaries of existing structures in the organization, so that the communication that occurs is functional (in the direction of their respective functions).

Whereas when viewed from an interpretive perspective, organizational communication is the process of creating meaning over the interaction that is an organization. ${ }^{10}$ Explained, the concept of 'meaning' of the meaning of communication in an interpretive perspective is essential to distinguish it from a functionalist perspective. In this interpretative sense it is shown that the meaning of a message is at the recipient. Another image of communication (subjective) indicates that the meaning of the message is negotiated between the participants. Thus, the relationship between the participants, will determine what the meaning of the words in question. Based on this also, the interpretive perspective, which means subjective, emphasizes the role of "people" and "processes" in creating meaning. The meaning is not only in people, but also on the "transaction" itself. ${ }^{11}$ Communication is the process of creating meaning over the interactions that create, nurture and change organizations. Communication like this according to Alo Liliweri more emphasis on methods and techniques that allow people to adapt to the environment of the organization. ${ }^{12}$

${ }^{8}$ Ibid, Page 31.

${ }^{9} \mathrm{Ibid}$, Page 33.

${ }^{10}$ Ibid.

${ }^{11}$ Ibid, Page 34. Page 59-60.

12 Alo Liliweri, (2004) Wacana Komunikasi Organisasi. Bandung: Remaja Rosdakarya, 


\section{Communication of Islamic Civic Organization in Overcoming the Conflict and Imaging at North Sumatera (analysis of muhammadiyah)}

Meanwhile, Goldhaber (1986) stated that "the definition of organizational communication as the process of creating and exchanging messages within a network of independent relationships to cope with environmental uncertainty ".13 (The process of creating and exchanging messages in a network of interdependent relationships to address an uncertain environment). Based on this definition, Goldhaber suggests there are seven concepts to note, namely: process, message, network (network), interdependence (interdependent), relationship (relationship), environment (environmental), and uncertainty (uncertainty). These seven concepts are explained by Goldhaber more broadly in his Organizational Communication. ${ }^{14}$

Departing from the seven concepts put forward Goldhaber above there are a number of concepts that are not only emphasized on the internal environment, but also external organizations. Concepts related to the externally defined organizational environments mentioned clearly and clearly are process, environment, and uncertainty. It means that internal organizational communication activities should be integrated with external organizational communication activities or vice versa. In the next discussion there are several sections that explain the relationship between internal organizational communication with external organizational communication.

\section{METHODOLOGY}

This research was a qualitative research (konstruktivis) with the aim to explain the phenomenon with deeply through the collection of data as deep. With this research, the data already collected must be deep and can explain the phenomenon being studied. Therefore, qualitative research is conducted to obtain the depth (quality) of data from research objects. Seen from the application of social research methods, this type of research belongs to research institutions, where research is focused on the study of social institutions. ${ }^{15}$ This research was focused on social organization (mass

13 Gerald M. Goldhaber, (1990). Organizational Communication. New York: Wm. C. Brown Publishers 5th Ed., hlm 16.

14 Ibid, Page 16 - 26.

${ }^{15}$ In research institutions that become the focus besides social institutions, can also take the object of study on society, culture, and various other institutions. Method of research of institution by using social research method must first: 1) specify the form or type of institution to be researched; 2) determine the problem to be studied which is closely related to the type of institution in question; and 3) formulate the problems and objectives of the research in accordance with the problems presented in the research plan. The types of institutions can be 
organizations) that is engaged in the social religious of Islam, namely Muhammadiyah, Nahdlatul Ulama, and Al Jam'iyatul Washliyah.

The location of this research is focused on the office of Muhammadiyah Regional Board of North Sumatera Province, located at Jalan SM Raja - Medan, Nahdlatul Ulama Regional Board of North Sumatera Province, having address at Jalan Sei Batang Hari - Medan, and Al Jam'iyatul Washliyah Regional Executive Board of North Sumatera Province which is located at Jalan SM Raja - Medan. As for the object of this research is all experiences, behaviors, actions, and activities that can be observed related to the communication undertaken / carried out as an effort to overcome the conflict and imaging in the three organizations studied.

To get the data deepest, so this research use data collecting technique as follows: Interview (interview), Documentation, Observation (observation).

\section{FINDINGS AND DISCUSSION}

\section{Muhammadiyah of North Sumatra}

The organizational structure of Muhammadiyah Regional Leadership (PWM) of North Sumatra illustrates the coordination of tasks. Between the higher positions and the other positions underneath it is an inseparable part, albeit hierarchically. Each position has its own roles and functions within the organization. The duties of each of these positions are described in the Muhammadiyah Household Bylaws. Therefore coordination of tasks is a process of providing motivation, lead, and communicate tasks to subordinates and peers to achieve organizational goals. In terms of coordination of these tasks the approach used is the system approach.

In the organizational structure of PWM North Sumatra, it is illustrated that the system approach sees coordination as a continuous integration, synchronization and simplification of the execution of tasks separately by a number of individuals or units so that everything is united in the right amount, the right quality, the right place, and the right time to reach the goal effectively and efficiently. The following will describe the tasks based on the organizational structure of PWM North Sumatra. In the

institutions or institutions, such as community organizations, judiciary, Religious Affairs Office (KUA), lobe, kiyai, ulama, perwakafan, grants, inheritance, and so forth. See Beni Ahmad Saebani, Research Method (Bandung: Loyal Pustaka, 2008),Page 120-121. 


\section{Communication of Islamic Civic Organization in Overcoming the Conflict and Imaging at North Sumatera (analysis of muhammadiyah)}

Muhammadiyah Household Rules (ART), particularly Article 11 Paragraph 1 to 7 on the Regional Leadership, it is argued that:

1. The Head of Region shall: a. Establish Muhammadiyah policy in its territory based on Central Leadership policy, Area Deliberative decision, Regional Level Leadership Meeting, and Leadership Meeting of Regional level. b. To guide and control the implementation of policy / instruction of the Central Executive and the Leader Elements. c. To guide and improve the business charity and activities of the region within its territory in accordance with its authority d. Foster, guide, integrate, and coordinate the activities of the Auxiliary Elements of Regional Autonomous Leaders and Organizations.

2. Regional Leaders are based in the provincial capital.

3. Members of the Regional Leadership may consist of men and women.

4. Members of the Regional Leaders shall be domiciled in the city of the Regional Head's office or in the vicinity.

5. The Regional Leadership shall appoint one of the Vice Chairs to be designated as a Tanwir member if the Chief Leader of the Area can not fulfill his duties as a Tanwir member.

6. The Regional Leadership may propose an additional member to the Regional Leadership Consultation of up to half of the elected members of the Regional Leadership, and shall be requested for approval by the Central Executive. During the wait of the decision of the Regional Leadership Meeting and the determination of the Central Executive, an additional candidate for the Regional Leadership member has been able to perform his duties on the responsibilities of the Regional Leadership.

7. The Regional Leader shall propose to the Regional Leadership Meeting the candidate for the successor of the Chief of the Regional Leader who, for some reason, stops within the grace period of the office to be determined and requested to be approved by the Central Executive. During the pending decision of the Regional Leadership Meeting and the determination of the 
Central Executive, the Chief of the Regional Leadership shall be held by one of the Vice Chairs for the decision of the Regional Leader. ${ }^{16}$

The provisions governing the Regional Deliberation in the framework of the stipulation of the management at the regional level, which is commonly termed the Regional Board (PW) mentioned in ART Muhammadiyah Article 24 Paragraph 1 to 8, as follows:

1. Regional Deliberations shall be held by and on the responsibility and presided over by the Regional Leadership.

2. Provisions on the implementation of the order, and the arrangement of the Regional Deliberative Council shall be determined by the Regional Leadership.

3. Invites and Regional Deliberations shall be sent to the Members of the Regional Deliberations no later than one month before the Regional Deliberation takes place. 4. Regional Deliberative Meeting:

a. Regional Leadership Report on: 1) Leadership Policy; 2) Organization; 3) Implementation of the decisions of the Congress, Tanwir, Instructions of the Central Executive, the execution of the decision of the Regional Deliberation, the Regional Leadership Meeting, and the Leadership Meeting of the Regional Level; and 4) Finance.

b. Program Area.

c. Election of Regional Leaders and Chairman's approval.

d. Election of Member of Tanwir Deputy Area.

e. The Problem of Muhammadiyah in the Territory.

f. Proposals.

5. Area Deliberations attended by:

a. Members of the Regional Deliberation shall consist of: 1) Members of the Regional Leaders who have been approved by the Central Executive; 2) Chairman of the Regional Head or his successor already authorized by the Regional Head; 3) Members of the Regional Leadership, whose numbers are determined by the Regional Heads; 4) Chairman of the Branch Manager or his successor authorized by the Regional Head; 5) Branch

16 Muhammadiyah Central Leadership, (2010). Articles of Association and Bylaws of Muhammadiyah 2005 (Yogyakarta: Muhammadiyah Central Leadership In cooperation with Suara Muhammadiyah. Page 39-40. 


\section{Communication of Islamic Civic Organization in Overcoming the Conflict and Imaging at North Sumatera (analysis of muhammadiyah)}

Representatives whose numbers are determined by the Regional Leaders based on the balance of the number of branches in each Branch; and 6) Vice Heads of Autonomous Region Level Organizations each of two persons.

b. Participants of the Regional Consultative Assembly shall consist of: 1) Representative of Sub-Regional Leadership Assistant Members, each of two persons; and 2) Special invitations from the Muhammadiyah determined by the Regional Leadership.

c. Regional Deliberation reviewers are those invited by the Regional Leaders.

6. The Regional Deliberative Member shall be entitled to express an opinion, vote, and be elected. Participants of Regional Deliberations are entitled to express an opinion. The Regional Deliberative Reviewer shall not be entitled to express an opinion, vote, and to be elected.

7. The Regional Deliberative Decision shall be reported to the Central Executive no later than one month after the Regional Deliberation. If within one month after the submission of the report, there is no explanation or objection from the Central Executive, the decision of the Regional Consultative Assembly may be accused by the Regional Leadership.

8. Meetings and or other activities held concurrently at the time of the Regional Deliberation shall be governed by the Organizer. ${ }^{17}$

By the coordination balances a number of different parts by aligning their interactions so that the entire organization moves to a defined destination effectively and efficiently as a system.

17 Ibid, Page 52-54. 


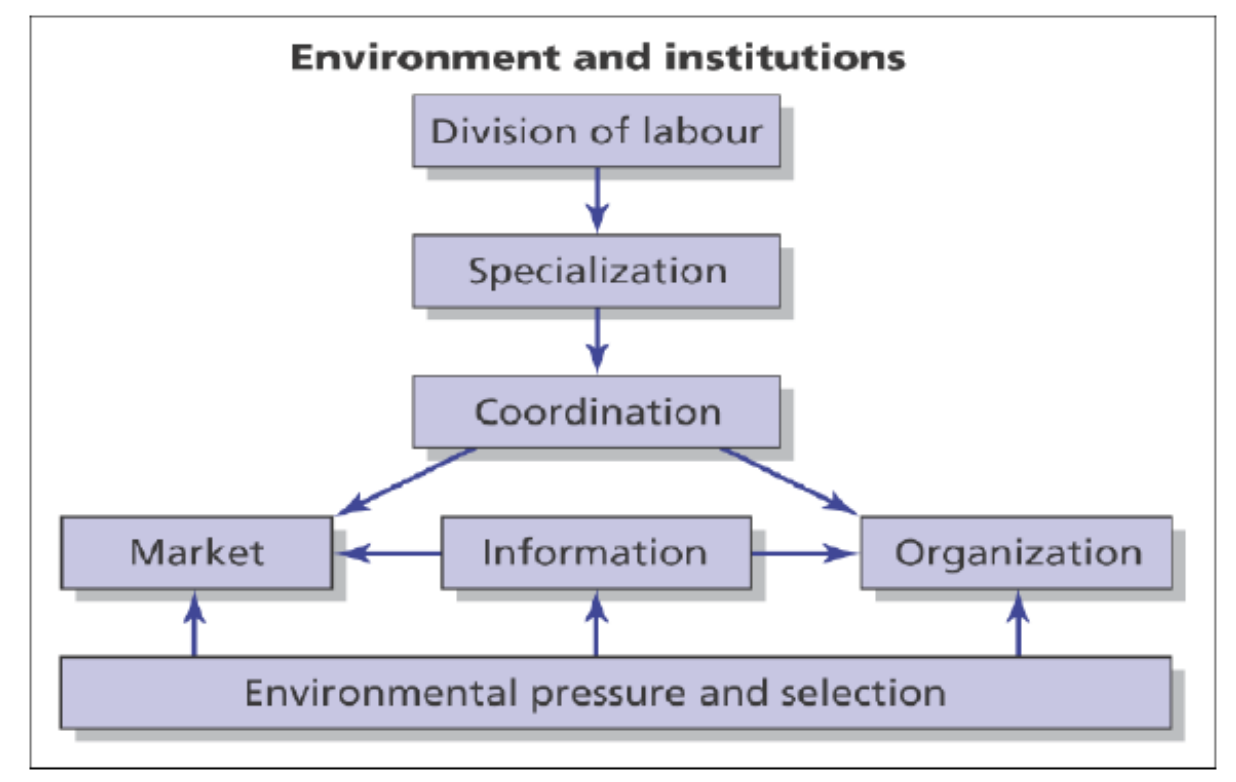

Taking into account the existence of Muhammadiyah North Sumatra as part of a large organization in Indonesia, in principle coordination of tasks running vertically, horizontally, and functionally. Vertical coordination is carried out in order to harmonious and synchronous cooperation harmonization from higher-level institutions to other institutions of lower degree. Horizontal coordination is done in order to harmonious and synchronous cooperation between institutions or equivalent units. While functional coordination is done in order to harmonious harmonious and synchronous cooperation between institutions that have similarities in job functions such as among fellow heads of public relations.

To see the principles of coordination which was abbreviated with COORDINATION. ${ }^{18}$

18 https://sumberbelajarsmkn10.wordpress.com/kompetensi-guru/kompetensikepribadian/koordinasi/, Accesed on 28/11/2016 Time 10.37 WIB. 


\section{Communication of Islamic Civic Organization in Overcoming the Conflict and Imaging at North Sumatera (analysis of muhammadiyah)}

\begin{tabular}{|c|c|c|}
\hline No. & Langkah-langkah & Penjelasan \\
\hline 1 & Kesamaan & $\begin{array}{l}\text { sama dalam visi, misi, dan langkah-langkah untuk } \\
\text { mencapaitujuan bersama (sense of purpose). }\end{array}$ \\
\hline 2 & Orientasikan & $\begin{array}{l}\text { titik pusatnya pada sekolah (sebagai koondinator) yang } \\
\text { simpul-sim pulnya stakeholders sekolah. }\end{array}$ \\
\hline 3 & Onganisasikan & $\begin{array}{l}\text { atur orang-onang yang berkoord inasi untuk membina } \\
\text { sekolah harus berada dalam satu payung (teronganisasi) } \\
\text { sehingga sikap egosektonal dapat dih indari. }\end{array}$ \\
\hline 4 & Rumuskan & $\begin{array}{l}\text { nyatakan secara je las wewenang, tanggung jawab, dan } \\
\text { tugas-tugas masing-masing agar tidak tumpang tindih. }\end{array}$ \\
\hline 5 & Diskusikan & $\begin{array}{l}\text { cari cara yang efektif, efisien, dan komunikatif dalam } \\
\text { berkoordinasi. }\end{array}$ \\
\hline 6 & Informasikan & $\begin{array}{l}\text { sem ua hasil diskusi dan keputusan mengalir cepat ke } \\
\text { sem ua pihak yang ada dalam sistem jaringan koond inasi } \\
\text { (coondination network system) }\end{array}$ \\
\hline 7 & Negosiasikan & $\begin{array}{l}\text { dakam perundingan mencari kesepakatan harus saling } \\
\text { menghormati (team spirit) dan usahakan menang-menang. } \\
\text { jangan sam pai pihak sekolah sebagai koordinator justru } \\
\text { dirugikan. }\end{array}$ \\
\hline 8 & Atur jadwal & $\begin{array}{l}\text { rencana kordinasi harus dipatuhi dengan sebaik-baiknya } \\
\text { oleh semua pihak Solusikan satu masalah dalam simpul } \\
\text { jaringan harus dirasakan dan dipecahkan sem ua } \\
\text { stakeholders dengan sebaik- baiknya. }\end{array}$ \\
\hline 9 & Insyapkan & $\begin{array}{l}\text { setiap harus stakeholders memiliki laponan tertulis yang } \\
\text { lengkap dan siap menginformasikannya sesuai kebutuhan } \\
\text { koordinasi. }\end{array}$ \\
\hline
\end{tabular}

The nature of coordination is the realization of a cooperation, mutual respect or appreciation of duties and functions and responsibilities due to the principle of the division of tasks, functionalization and consequence of a range or level of control, in which the leader must foster, guide, direct and control various activities in a large and complex organization, where various functions and activities must be performed by various units of work (units) that must be done in an integrated and simultaneous manner.

In general, coordination is a binding strap within organizations and management that connects the roles of organizational and management boards to achieve organizational and management objectives. In other words, coordination can ensure the movement of organizational leaders toward common goals. Without coordination, all parties in the organization and management will move in accordance 


\section{Hasnun Jauhari Ritonga}

with their interests but regardless of the role of other boards in the organization and the role of each board is not necessarily to achieve a common goal.19

\section{CONCLUSION}

In Indonesia, religious social organizations have continued to develop, but some have been established, such as Muhammadiyah, NU, and Al Washliyah. These three organizations include those already established, with the exception that $\mathrm{Al}$ Washliyah is especially more established in North Sumatra as a place of birth. Even some of the organizations that had made rapid progress, have now declined, such as Al Ittihadiyah, Persatuan Islam (Persis), and Dewan Dakwah Islamiyah Indonesia (DDII). While the Council of Muslim Shuro Indonesia (Masyumi) for example, has long disappeared from the political and social arena of society in Indonesia, but formerly including organizations that advanced and respected all parties.

On the one hand, the emergence of various social organizations based on religious communities in Indonesia is a blessing for Muslims, because it can contribute to the community in various segments of life, such as religious, education, health, and so forth. But on the other side it is also veiled-even sometimes open in front of the eyes of Muslims themselves.

Another thing that needs attention is the existence of egocentrism within the organizational boards. When there is one issue that should require a common understanding of the issue, it is not communicated to one another. There is no intensive communication between one organization and another. The problem then, where is the role of religious organizations as a gatekeeper (gatekeeper) giving information to Muslims? Of course the answer is not as simple as imagined. It takes a joint commitment among the organizers of the organization to have inter-institutional communication that is in the name of religion and Muslims. For that required communication between organizations

\section{BIBILIOGRAPHY}

Effendy, O. U (1985). Ilmu Komunikasi: Teori dan Praktek. Bandung: Remaja Rosdakarya.

19 See http://www.kompasiana.com/nur_maya/fungsi-koordinasi-dalam-sebuahorganisasi_551f984b813311f0379df203, Accesed on 28/11/2016 Time 10.50 WIB. 


\section{Communication of Islamic Civic Organization in Overcoming the Conflict and Imaging at North Sumatera (analysis of muhammadiyah)}

Goldhaber, G. M. (1990). Organizational Communication 5th Ed.. New York: Wm. C. Brown Publishers

Liliweri, A. (2004) Wacana Komunikasi Organisasi. Bandung: Remaja Rosdakarya.

Muhammad, A. (2011). Komunikasi Organisasi. Jakarta: Bumi Aksara.

Nurudin, (2008). Sistem Komunikasi Indonesia. Jakarta: Raja Grafindo Persada,

Pimpinan Pusat Muhammadiyah, (2010). Anggaran Dasar dan Anggaran Rumah Tangga Muhammadiyah 2005 (Yogyakarta: Pimpinan Pusat Muhammadiyah Bekerjasama dengan Suara Muhammadiyah.

R. Wayne Pace \& Don F. Faules, (2005). Komunikasi Organisasi: Strategi Meningkatkan Kinerja Perusahan (terj.) Deddy Mulyana. Bandung: Remaja Rosdakarya.

Rakhmat, J. (2005) Psikologi Komunikasi (Bandung: Remaja Rosdakarya

Yuwono, S. (1985). Ikhtisar Komunikasi Administrasi. Yogyakarta: Liberty.

https://sumberbelajarsmkn10.wordpress.com/kompetensi-guru/kompetensikepribadian/koordinasi/, Accesed on 28/11/2016 time 0.37 WIB.

http://www.kompasiana.com/nur_maya/fungsi-koordinasi-dalam-sebuahorganisasi_551f984b813311f0379df203, Accesed on 28/11/2016 Time 10.50 WIB. 